\section{Metal contamination of the St. Lawrence River following a major release of untreated wastewater}

\author{
C. Gagnon, M. Pilote, P. Turcotte, \\ C. André
}

Centre Saint-Laurent, Water Science \& Technology, Environment and Climate Change Canada, Montréal, Québec

\section{Introduction}

Nearly 5 billion liters of untreated sewage was intentionally discharged in November 2015 in the St. Lawrence River (Canada) for reasons of major sewer system maintenance and to avoid jeopardizing the Montreal wastewater treatment plant. For more than 4 days, discharge points and dispersion plumes were significant and clearly visible along the banks of the island of Montreal. A previous study on sub-lethal effects associated to this untreated wastewater release event reported adverse toxic effects such as DNA damage. ${ }^{1}$ Municipal wastewaters are sources of many toxic contaminants including metals. ${ }^{2}$ As usually the Montreal wastewater treatment plant significantly reduces the particulate load, ${ }^{3}$ this type of spill would represent a contribution of particulate matter and associated contaminants, like metals, to receiving waters. Metal partitioning (i.e., phase distribution) influences the transport and mobility of contaminants in fluvial ecosystems, for instance, and metal bioavailability to aquatic organisms as well., 4

As a first objective, the enrichment in metals was assessed at the discharge points of untreated wastewaters and in surface waters further downstream. As a second objective, the phase distribution and the behavior of rejected metals were studied by assessing the $\mathrm{Kd}$ distribution coefficients in the surface waters.

\section{Materials and Methods}

Four sites nearby untreated wastewater discharge overflows were visited during and after the event: McGill overflow close to old port area and downtown Montreal; Pier No. 46 in the western industrial port area; Bellerive Park near a residential sector; and St-Jean-Baptiste downstream petro chemistry industries (Figure 1). In situ conductivity measurements were used for tracking wastewater dispersion plumes. Further, in order to determine the relative long-distance transport of contaminants, water samples were also collected at the end of the Montréal island about $19 \mathrm{~km}$ downstream along a four sampling point transect $(0.1$ to $2 \mathrm{~km})$ between the Montreal shoreline and the St. Lawrence Seaway (Figure 1).

Water samples were collected in Teflon bottles at $1 \mathrm{~m}$ below the water surface with an acid-clean Teflon pump equipped with trace metal clean Teflon tubing. Samples (200-500 mL) for metal analysis were filtered on $0.45 \mu \mathrm{m}$ metal-free Teflon filters (FHLC Millipore) under a class-100 laminar hood. Total fraction and filtered water samples were then acidified with $\mathrm{Q}-\mathrm{HNO}_{3}$ (SeaStar Baseline grade) and stored in acidclean LDPE bottles until analysis, while $\mathrm{Hg}$ and $\mathrm{MeHg}$ samples were stored in Teflon bottles. Trace metals were determined by ion-coupled plasma mass spectrometry (ICP-MS; X Series II Thermo Scientific) while total mercury was analyzed by coldvapor atomic fluorescence spectroscopy (CVAFS; US-EPA, Method 1631). ${ }^{6,7}$ Mercury in non-filtered water samples was determined using two-stage gold amalgamation with gas phase detection while methylmercury (MeHg) samples were previously distillated and ethylated before detection (US-EPA, Method 1630). ${ }^{8}$ Relative standard deviation (RSD) values were better than $7 \%$. Partition coefficients (Kd) were calculated as the concentration of metal $\mathrm{g}^{-1}$ particle divided by the concentration of dissolved metal $\mathrm{mL}^{-1}$ water. ${ }^{9}$ Surface water characteristics ( $\mathrm{pH}$, conductivity, suspended particulate matter, dissolved oxygen) were measured on-site and total fecal coliform plate counts were carried out. ${ }^{10}$

\section{Results and Discussion}

Water parameters such as $\mathrm{pH}$, conductivity, dissolved oxygen, suspended particulate matter (SPM) and coliforms were determined as indicators of water quality during the wastewater discharge event (Table 1). Increases in SPM concentrations, up to 4 times relative to the post-event levels (2 weeks after), highlights the particle loading caused by the release of untreated wastewaters. At McGill site, SPM values were even higher than concentrations reported in the dispersion plume of the treated effluent $(6.3 \mathrm{mg} / \mathrm{L}$ at $0.5 \mathrm{~km}$ downstream the outfall). ${ }^{4}$ While $\mathrm{pH}$ values were not significantly affected, conductivity values were significantly increased, with doubled values at McGill site in respect to the post-even values. Such changes were similarly observed for coliforms with an enrichment factor of 75,000 at this site confirming high impact
Correspondence: Christian Gagnon, Water Science \& Technology, Environment and Climate Change Canada, 105 McGill, $7^{\text {th }}$ floor, Montreal, Canada.

E-mail: Christian.gagnon@canada.ca

Key words: Metal; wastewater; fate; partitioning; transport.

Acknowledgments: this study was supported by the St. Lawrence Action Plan of Environment and Climate Change Canada.

Funding: Plan Action Saint-Laurent.

Conference presentation: part of this paper was presented at St. Lawrence Chapter meeting, Society of Environmental Chemistry and Toxicology, 2017 June, Montreal. Canada.

This work is licensed under a Creative Commons Attribution NonCommercial 4.0 License (CC BY-NC 4.0).

(C) Copyright C. Gagnon et al., 2017

Licensee PAGEPress, Italy

Journal of Xenobiotics 2017; 7:7173

doi:10.4081/xeno.2017.7173

on water quality.

The highest metal concentrations were observed at the McGill site during the event. While those concentrations did not generally exceed water quality guidelines, ${ }^{11}$ the untreated wastewater discharges are seen as an additional contribution to the overall contamination of the SaintLawrence River ecosystem. Metal concentrations increased near discharge points with enrichment factors up to 14-fold when compared to post-event levels (Figure 2). Increases in concentrations were reported for all metals where most metals increased by an average factor of $180 \%$. High enrichment factors (up to $2000 \%$ ) were calculated for $\mathrm{Cu}$ and $\mathrm{Zn}$. Total mercury and its methylated form (not shown) significantly increased (up to $700 \%$ ) during the event. As already reported for this discharge event, conductivity was positively correlated with all metals $(r>0.90, \mathrm{P}<0.001)$ and SPM also positively correlated with most metals $(\mathrm{r}>0.88, \mathrm{P}<0.001){ }^{1}$

\section{Conclusions}

Concentrations of metals were also measured further downstream (19 km) along a transect between Montreal shoreline and the St. Lawrence Seaway and the most significant changes were observed at the closest $(100 \mathrm{~m})$ station 0A from the shore 
(unpublished data). Downstream all the discharge points, increases $(200 \%)$ in SPM were observed at the station $0 \mathrm{~A}$ but resumed at initial concentrations after the event (Table 1). All metal concentrations significantly increased during the discharge period (Figure 3). Enrichment factors were no more than $300 \%$ for most metals (i.e., Ag, $\mathrm{Cd}, \mathrm{Cr}, \mathrm{Pb}, \mathrm{Cu}, \mathrm{Hg}$. $\mathrm{MeHg}, \mathrm{Mn}$, and $\mathrm{Zn}$ ) and up to $1200 \%$ for Co and V. Then after the event, all metal concentrations returned to initial concentrations.

The discharge of untreated wastewater had impacts on metal phase distribution as revealed by calculated partitioning coefficient Kd (Figure 2). During the discharge event, $\mathrm{Kd}$ values significantly increased for metals such as $\mathrm{Cr}, \mathrm{Mn}$, and $\mathrm{Ni}$ with the highest increases for $\mathrm{Ag}, \mathrm{Cu}, \mathrm{Cr}$ and $\mathrm{Pb}$ (up to five folds) at St-Jean-Baptiste site when compared to values after the event. These phase distribution changes indicated a larger metal association with the particulate phase. Generally observed Kd values could be partly explained by changes in SPM concentrations. However, the lowest changes in $\mathrm{Kd}$ values were observed at the McGill site (Figure 2) where SPM concentrations were the highest $(>200 \%$; Table 1$)$. This observation could point out the importance of water chemistry changes on metal partitioning, which would modify exposure routes to aquatic organisms. ${ }^{12}$ Such changes in metal partitioning also influence their fate and transport and would have likely favored accumulation in low-flow sedimentation zones further downstream. All these results on metal distribution and phase partitioning as well contribute to a better evaluation of the metallic contamination associated with the dispersion of untreated wastewater. Moreover, this study helps understanding impacts of increased releases of untreated wastewater under climate changes caused by more frequent and intense rainfall events. ${ }^{13}$

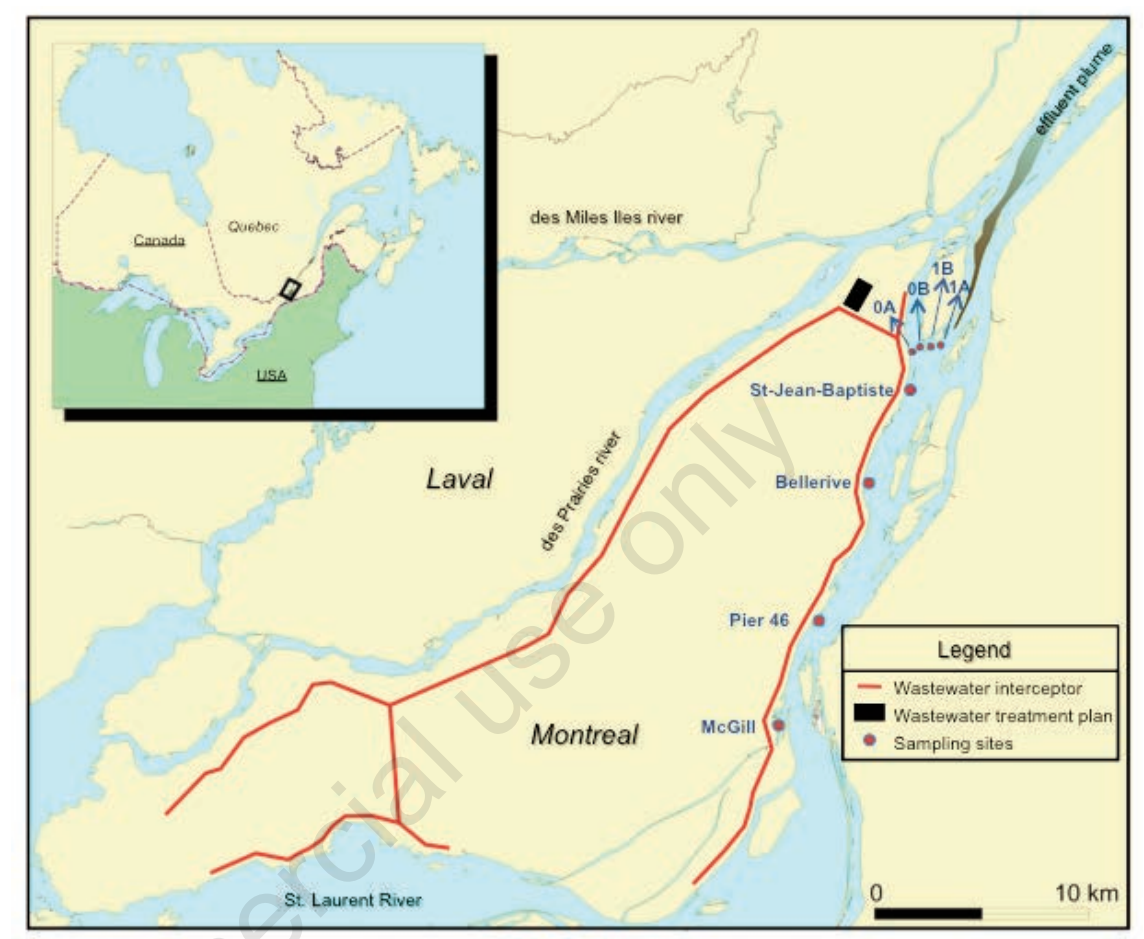

Figure 1. Sampling sites near discharge points in the St. Lawrence River and along a transect further downstream Montreal Island (Canada).

Table 1. Water quality parameters measured prior, during and after the untreated wastewater discharge event.

\begin{tabular}{|c|c|c|c|c|c|c|}
\hline Period & Site & pH & $\begin{array}{l}\text { Conductivity } \\
\text { (11s/cm) }\end{array}$ & $\begin{array}{l}\text { Oxygen } \\
\text { (mg/L) }\end{array}$ & $\begin{array}{l}\text { TSM } \\
(\mathrm{mg} / \mathrm{L})\end{array}$ & $\begin{array}{c}\text { Coliforms } \\
\text { (UFC/100mL) }\end{array}$ \\
\hline $\begin{array}{l}\text { Pre-event } \\
\text { (7 days before) }\end{array}$ & $\begin{array}{l}0 \mathrm{~A} \\
0 \mathrm{~B} \\
1 \mathrm{~B} \\
1 \mathrm{~A}\end{array}$ & $\begin{array}{l}8.3 \\
8.3 \\
8.1 \\
7.9\end{array}$ & $\begin{array}{l}297.1 \\
294.9 \\
296.2 \\
297.3\end{array}$ & $\begin{array}{l}10.7 \\
10.5 \\
10.6 \\
10.5\end{array}$ & $\begin{array}{l}1.9 \\
2.3 \\
2.2 \\
2.2\end{array}$ & $\begin{array}{l}- \\
- \\
- \\
-\end{array}$ \\
\hline Event & $\begin{array}{l}\text { McGill } \\
\text { Pier } 46 \\
\text { Bellerive } \\
\text { St-Jean-Baptiste } \\
\text { OA } \\
\text { OB } \\
\text { 1B } \\
\text { 1A }\end{array}$ & $\begin{array}{l}7.3 \\
8.1 \\
8.1 \\
8.2 \\
7.8 \\
7.9 \\
8.0 \\
8.0\end{array}$ & $\begin{array}{l}505.0 \\
280.0 \\
330.7 \\
308.1 \\
295.6 \\
289.9 \\
286.7 \\
286.0 \\
\end{array}$ & $\begin{array}{c}8.2 \\
11.1 \\
10.6 \\
10.8 \\
10.9 \\
11.0 \\
11.1 \\
11.1 \\
\end{array}$ & $\begin{array}{l}8.0 \\
3.5 \\
4.3 \\
2.5 \\
2.8 \\
4.5 \\
4.4 \\
4.1\end{array}$ & $\begin{array}{c}750000 \\
10000 \\
10000 \\
69000 \\
13000 \\
8400 \\
6300 \\
5800 \\
\end{array}$ \\
\hline $\begin{array}{l}\text { Post-event } \\
\text { (25 days after) }\end{array}$ & $\begin{array}{l}\text { McGill } \\
\text { Pier } 46 \\
\text { Bellerive } \\
\text { St-Jean-Baptiste } \\
\text { OA } \\
\text { OB } \\
\text { 1B } \\
\text { 1A }\end{array}$ & $\begin{array}{l}7.4 \\
7.6 \\
8.2 \\
8.2 \\
8.3 \\
8.2 \\
8.2 \\
8.2\end{array}$ & $\begin{array}{l}235.9 \\
249.3 \\
255.9 \\
259.4 \\
258.8 \\
258.4 \\
266.2 \\
265.3 \\
\end{array}$ & $\begin{array}{l}12.8 \\
12.8 \\
12.7 \\
12.8 \\
12.9 \\
12.7 \\
12.7 \\
12.7\end{array}$ & $\begin{array}{l}1.8 \\
1.7 \\
1.9 \\
2.3 \\
1.5 \\
1.7 \\
1.3 \\
1.5\end{array}$ & $\begin{array}{l}10 \\
10 \\
10 \\
90 \\
<10 \\
<10 \\
<10 \\
<10\end{array}$ \\
\hline
\end{tabular}



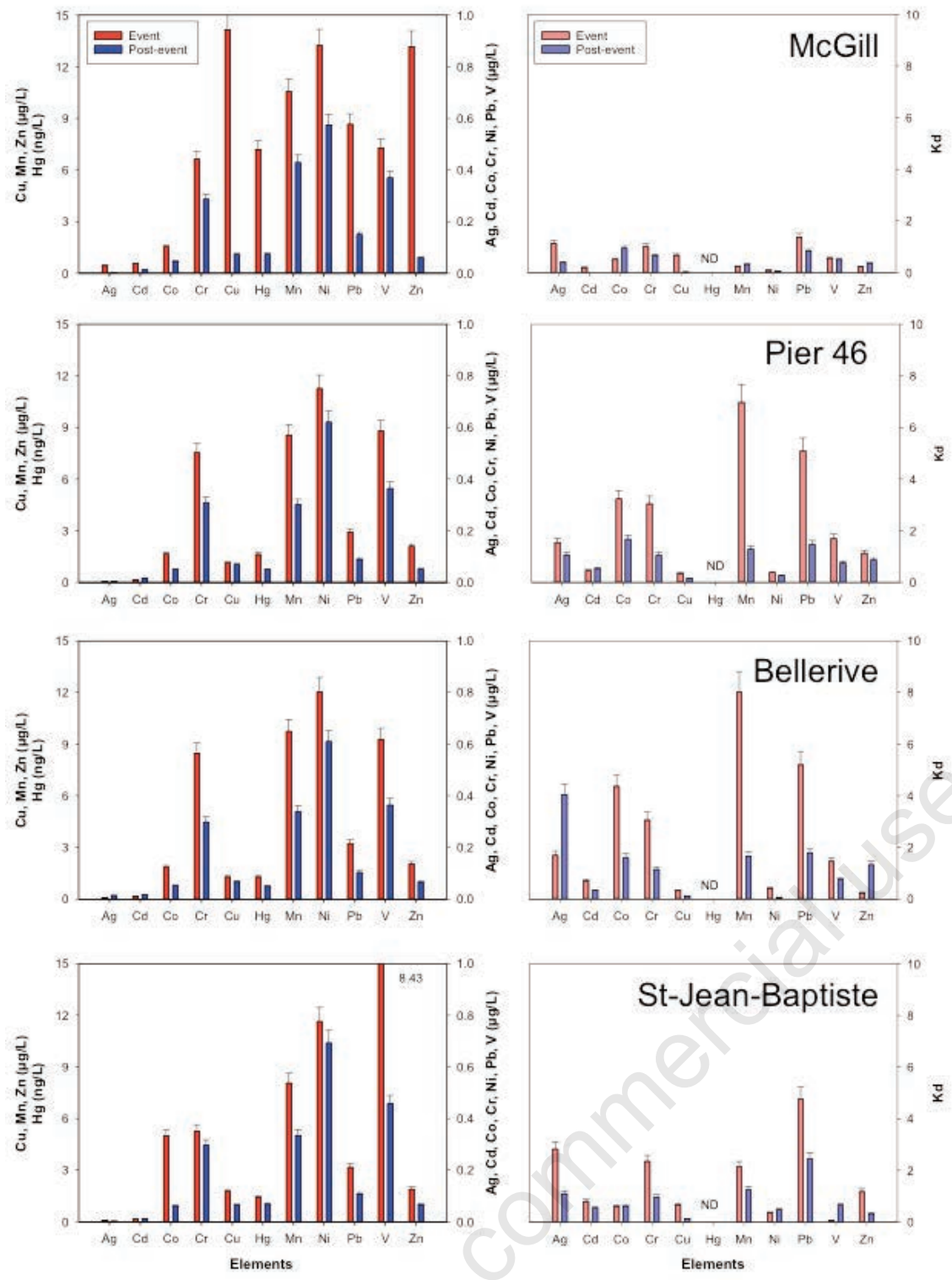

Figure 2. Total metal concentrations (left) and partitioning coefficient Kd (right) at discharge points during and after the event.
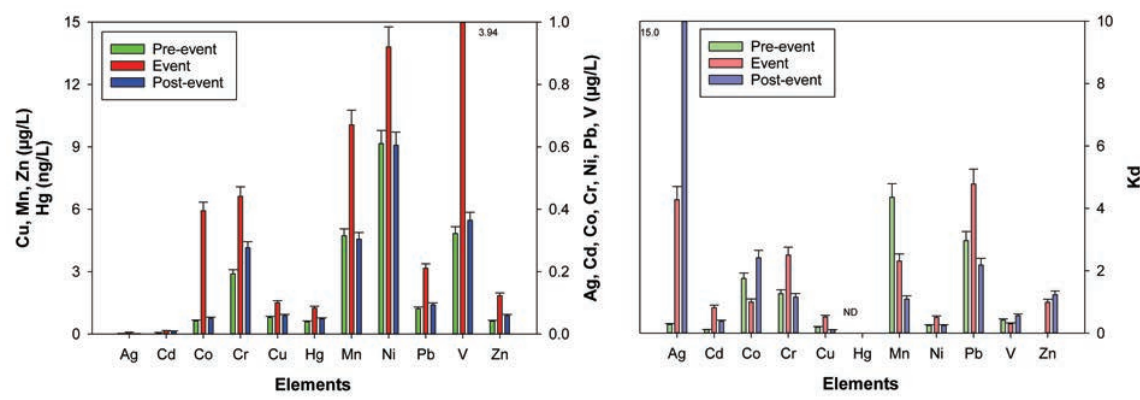

Figure 3. Total metal concentrations (left) and partitioning coefficient Kd (right) at further downstream $(19 \mathrm{~km})$ in the St. Lawrence river prior, during and after the event.

\section{References}

1. Gagné F, André C, Pilote M, Turcotte P, Gagnon C. Toxicological properties of a major release of untreated wastewaters into the St. Lawrence River to quagga mussels Dreissena bugensis. Invert Surv J 2017;14:352-62.

2. Chambers PA, Allard M, Walker SL, Marsalek J, Lawrence J, Servos M, et al. Impacts of municipal wastewater effluents on Canadian waters: A review. Water Qual Res J Can 1997;32:659713.

3. Marcogliese DJ, Blaise C, Cyr D, de Lafontaine Y, Fournier M, Gagné F, et al. Effects of a major municipal effluent on the St. Lawrence River: A case study. AMBIO J 2015;44:257-74.

4. Gagnon C, Turcotte P. Role of colloids in the physical speciation of metals in the dispersion plume of a major municipal effluent. Revue Sci Eau 2007;20: 275-85.

5. Jamali MK, Kazi TG, Afridi HI, Arain MB, Jalbani N, Menon AR. Speciation of heavy metals in untreated domestic wastewater sludge by time saving BCR sequential extraction method. J Environ Sci Health Part A 2007;42:649-59.

6. Bloom NS, Fitzgerald WF. Determination of volatile mercury species at the picogram level by lowtemperature gas chromatography with cold-vapor atomic fluorescence detection. Anal Chim Acta 1988;208:151.

7. United States Environmental Protection Agency [US-EPA]. Method 1631, Revision E: Mercury in water by oxidation, purge and trap, and cold vapor atomic fluorescence spectrometry. 2002; EPA-821-R-02-019, 45 pp.

8. United States Environmental Protection Agency [US-EPA]. Method 1630, Methyl mercury in water by distillation, Aqueous ethylation, purge and trap, and cold vapor atomic fluorescence spectrometry. 2001; EPA 821-R-01-020, 55 pp.

9. Gagnon C, Turcotte P, Vigneault B. Comparative study of the fate and mobility of metals discharged in mining and urban effluents using sequential extractions on suspended solids. Environ Geochem Health 2009;31:65771.

10. American Public Health Association [ALPHA]. American Water Works Association and Water Environment Federation. In Standard Methods for the Examination of Water and Wastewater, $22^{\text {nd }}$ ed., 2012.

11. Canadian Council of the Ministers of the Environment [CCME]. Canadian 
Water Quality Guidelines for the Protection of Aquatic Life. 2006, Summary Table. Update 6.0.1.

12. Pan J-F, Wang W-X. Influences of dis- solved and colloidal organic carbon on the uptake of $\mathrm{Ag}, \mathrm{Cd}$, and $\mathrm{Cr}$ by the marine mussel Perna viridis. Environ Pollut 2004;129:467-77.
13. Min S-K, Zhang X, Zwiers FW, Hegert GC. Human contribution to moreintense precipitation extremes. Nature 2011;470:378-81. 